\title{
An Evaluation of the Publications in the Field of Geography Education: Bibliometric Analysis Based on the Web of Science Database
}

\author{
Bülent AKSOY 1 \\ Gazi University, Ankara, TURKEY
}

\author{
Kerem BOZDOĞAN ${ }^{2}$ \\ Gözüakçalar Primary School, Kayseri, TURKEY
}

\section{Ömer Faruk SÖNMEZ 3 \\ Tokat Gaziosmanpasa University, Tokat, TURKEY}

${ }^{1}$ Prof. Dr. Gazi University, Faculty of Education, Turkish and Social Sciences Department, Ankara, TURKEY. baksoy28 [at] gmail.com. ORCID: 0000-0002-7181-8008

2Corresponding author: Dr., Ministiry of Natioal Education, Classroom Teacher at Kayseri Gözüakçalar Primary School Kayseri, Turkey. E-Mail: kb_38[at] hotmail.com. ORCID: 0000-0003-0605-2031

${ }^{3}$ Prof. Dr., Tokat Gaziosmanpaşa University, Educational Faculty, Turkish and Social Sciences Department, Tokat-Turkiye, sonmez.omerfaruk [at] gmail.com , ORCID: 0000-0002-8910-2817

\begin{abstract}
The purpose of this study is to examine scientific publications about Geography Education in terms of bibliometric indicators. Case study method, one of the qualitative research methods, was applied in this study. The scanning range of bibliometric data obtained from the WoS database generated by Clarivate Analytics covers the dates between 1975 and March 2020. The bibliometric analysis technique was conducted in the study. As a result of the analyses, it was revealed that 559 of 64,874,978 studies registered in the WoS database between 1975 and 2020 were the studies related to Geography Education. It was also observed that 196 (35.06\%) of these records were in the education / training research category. Through the analyses, it was concluded that the most common type of publication related to Geography Education was the articles with a total number of 196. Moreover, it is seen that approximately 106 of the published articles have been published during the years between 2016 and 2020. This rate indicates that the educational researches related to Geography Education have increased in recent years. In addition, at the end of the analyses, it was comprehended that there are 330 different authors contributing to the related field. It was determined that a total of 535 different keywords were utilized in 196 articles, and the most effective journal was the "Journal of Geography and Environmental Education". Besides, it is observed that the researchers from 25 different countries have published some articles that contribute to the field. In this regard, the most active country is the United States, and it is respectively followed by Britain, Australia, and Turkey. That Turkey with 18 articles takes place at the $4^{\text {th }}$ rank among the 25 different countries indicates that some comprehensive studies related to this field are carried out.
\end{abstract}

\section{Keywords}

Geography Education, Bibliometrics, Web of Science 
At present, the importance of geography and geography education is increasing. Recent developments in the world are considered as the proof of this situation. The spread of the contagious feature of Covid 19 disease, which has recently influenced the whole world, to the countries across the World, the daily news about it in the written and visual media, and its location in the various countries in the world are known only through the geography. Almost every segment of the society tried to imagine the countries that are the source of this news on the world map. This is the closest indication of how important the geography is in all our lives. Depending on the globalization, the need for geographic knowledge, skills, and perspectives increases among people since the world is increasingly tied together (Kizılcaoğlu and Taş, 2007: 94). It is a fact that the geography includes the information that facilitates the lives of people (Yıldırım, 2016: 851). In general, the geography is a social science, but it prepares the individuals for life in many aspects (Bednarz, Heffron \& Huynh, 2013: 7). In this context, it is necessary to educate the individuals so as to enable them to acquire active, responsible, and global citizenship against the local or global difficulties according to the common opinion of many geography educators (Değirmenci, 2019: 3287). In this process, all the attention is taken to the geography education. Through the geography education, it is also purposed that the students understand different places, natural structure, people, economies, cultures, and their connections and relations with them (Gökçe \& Öztürk, 2013: 93). Only through individuals who achieve these requirements can the countries make sense of the future of their environment and the world, the effect of different cultures, lives, interactions in the world (Kılcan, Çetin, Ablak and Gürgür, 2019: 915). In this regard, because the geography education is important, an understanding of teaching that enables learning by doing and living in geography education programs has been created (Koç, Aksoy, Sönmez and Yeşiltaş, 2010: 183). When the literature is examined, it is seen that there are some researches (Gregg \& Leinhardt (1994), Kızılçaoğlu (2003), Nairn (2005), Akınoğlu (2005), Cotton (2006), Karasu and Ünlü (2006), Gibson (2007), Murphy (2007), about geography education and training. Demiralp (2007), Artvinli (2009), Korkmaz \& Karakus, (2009), İncekara (2009), Brooks (2010), Koç \& Aksoy (2010), Artvinli \& Kaya (2010), Geçit (2010), Koç, Sonmez \& Çifçi (2012), Balcı (2012), Kaya (2013), Sönmez, Koç \& Çifçi (2013), Butt \& Lambert (2014), Çiftçi (2017)) related to the orientations of geography education. When the literature is evaluated, it is observed that there are researches about geography education, geography curriculum, geography special teaching methods, and teaching many subjects of geography. It can be stated that the studies mostly focus on geography education and teaching. Studies in the form of bibliometric analysis of geography education were found to be at the point of examining masters and doctoral theses through a narrow scope. No in-depth bibliometric analysis was detected in the literature. At this point, it is important and necessary to measure the scientific researches related to geography education by applying bibliometric methods. The purpose of bibliometric studies is to examine the increase rate and development of studies carried out in a specific research area or discipline, and to evaluate the current status of scientific publication policies of institutions and countries (Demirgil, 2018: 38). Accordingly, this study purposes to examine the academic publications related to geography education in terms of bibliometric indicators. 
Based on this purpose, the answers to the following research questions were sought in the research:

- What are the WOS categories of the publications scanned with the keyword of "geography education"?

- What are the types of publications regarding geography education within the scope of education / educational research?

- How is the distribution of the articles published on geography education in education / educational research category by publication years?

- What are the top 10 most-cited articles for geography education in the education / educational research category?

- What are the most contributing authors and publications in the field of geography education in the education / educational research category?

- Which journals are active in the scope of articles published about geography education in education / educational research category?

- Which countries are effective within the scope of articles published about geography education in education / educational research category?

- Which publication languages are effective in the scope of articles related to geography education in the category of education / educational research?

- What are the funds that support the published articles about geography education in the education / educational research category?

What are the articles on geography education that were published in turkey in the category of education / educational research?

\section{Methodology}

\section{Model of the Research}

The model of the research is in the case study format from the qualitative research designs. The purpose of the case study is to reveal the results related to a particular case (Yıldırım \& Şimşek, 2013). The study was designed in the case study format because it was purposed to determine the current status of educational research articles and academic publications in the field of geography education.

\section{Data Collection Tools}

The data of this study were obtained from the international citation directories using Web of Science. The keyword of "geography education" was searched both in the article titles and in the article content. An online scan of 1975-1 March 2020 was carried out in the WoS database. The scanned indexes were determined as SCI-Expanded, SSCI, A \& HCI, CPCI-S, CPCI-SSH, BKCI-S, BKCI-SSH, and ESCI. 559 records out of a total of $64,874,978$ records emerged during the screening process. 196 of these records are within the scope of education / training researches, and the study in question is limited to the article with the most registration type. The obtained findings are presented through the tables in the study. 
Aksoy, B.; Bozdoğan, K.; Sönmez, Ö. F. (2021). An evaluation of the publications in the field of...

\section{Data Analysis}

Bibliometric was applied as data analysis method in the study. The term bibliometric refers to the mathematical and statistical analysis of models that appear in publications and document types (Diodato, 1994). Bibliometric analysis can be used to develop measures that evaluate the scientific productivity and impact in a journal (Reaves et al., 2017). The visibility of geography education in scientific studies is tried to be revealed in this study. The WoS Categories of the Publications Scanned with the Keyword of "Geography Education", The Types of Publications on Geography Education within the Scope of Education / Education Research, Distribution of Articles on Geography Education Published in the Education / Education Research Category by Publication Years, The Top 10 MostCited Articles, The Number of Authors and Publications That Provided the Most Contribution to the Field in the Scope of Geography Education in Education / Education Research Category, Journals Effective in the Scope of Articles on Geography Education Published in the Education / Education Research Category, Countries Effective in the Scope of Articles on Geography Education Published in the Education / Education Research Category, Institutions Effective in the Scope of Articles on Geography Education Published in the Education / Education Research Category, Publication Languages Effective in the Scope of Articles on Geography Education Published in the Education / Education Research Category, Funds Supporting the Published Articles on Geography Education in Education / Educational Research Category, and the Articles on Geography Education Published in Turkey in the category of Education / Educational were variably analyzed in this context. WoS categories of 559 studies that emerged as a result of online scanning were examined. In the study, the keyword network map was created by using the VOSviewer (Version 1.6.9) package program.

\section{Findings}

WoS categories of 559 studies that emerged as a result of online scanning were examined, and the first 8 categories are presented in Table 1.

Table 1

WoS Categories of Publications Scanned with the Keyword of "Geography Education" (The top 8 categories)

\begin{tabular}{lc}
\hline WoS Categories & Number of Records \\
\hline 1. Education / Educational Research ${ }^{*}$ & 196 \\
\hline 2. Geography & 84 \\
\hline 3. Interdisciplinary Computer Science Applications & 3 \\
\hline 4. Environmental Studies & 2 \\
\hline 5. Green and Sustainable Science Technology & 2 \\
\hline 6. Educational Psychology & 2 \\
\hline 7. Field Studies & 1 \\
\hline 8. Educational Sciences Disciplines & 1 \\
\hline
\end{tabular}

Examining Table 1, it is observed that whereas the most records are in the category of "Education / Educational Research" with the total number of 196 studies, this is followed by "Geography" with 84 studies, "Interdisciplinary Computer Science Applications" with 3 studies, "Environmental Studies", "Green 
and Sustainable Science Technology", "Educational Psychology" with 2 studies for each, and other categories with 1 study for each.

Publications in the Education / Training Research category were examined according to their types, and the findings are presented in Table 2.

Table 2

Publication Types on Geography Education within the Scope of Education / Educational Research

\begin{tabular}{lc}
\hline WoS Categories & Number of Records \\
\hline 1.Article $1^{*}$ & 196 \\
\hline 2. Book Chapter & 30 \\
\hline 3. Open Access & 12 \\
\hline 4. Paper & 10 \\
\hline
\end{tabular}

According to Table 2, the most common type of publication is the articles with 196 studies, and this type is respectively followed by book chapters with a total number of 30 studies, open access with 12 studies, and paper with 10 studies.

The keywords of the articles related to Geography Education in the Education / Educational Research category were examined, and the keyword network is presented in Graphic 1.

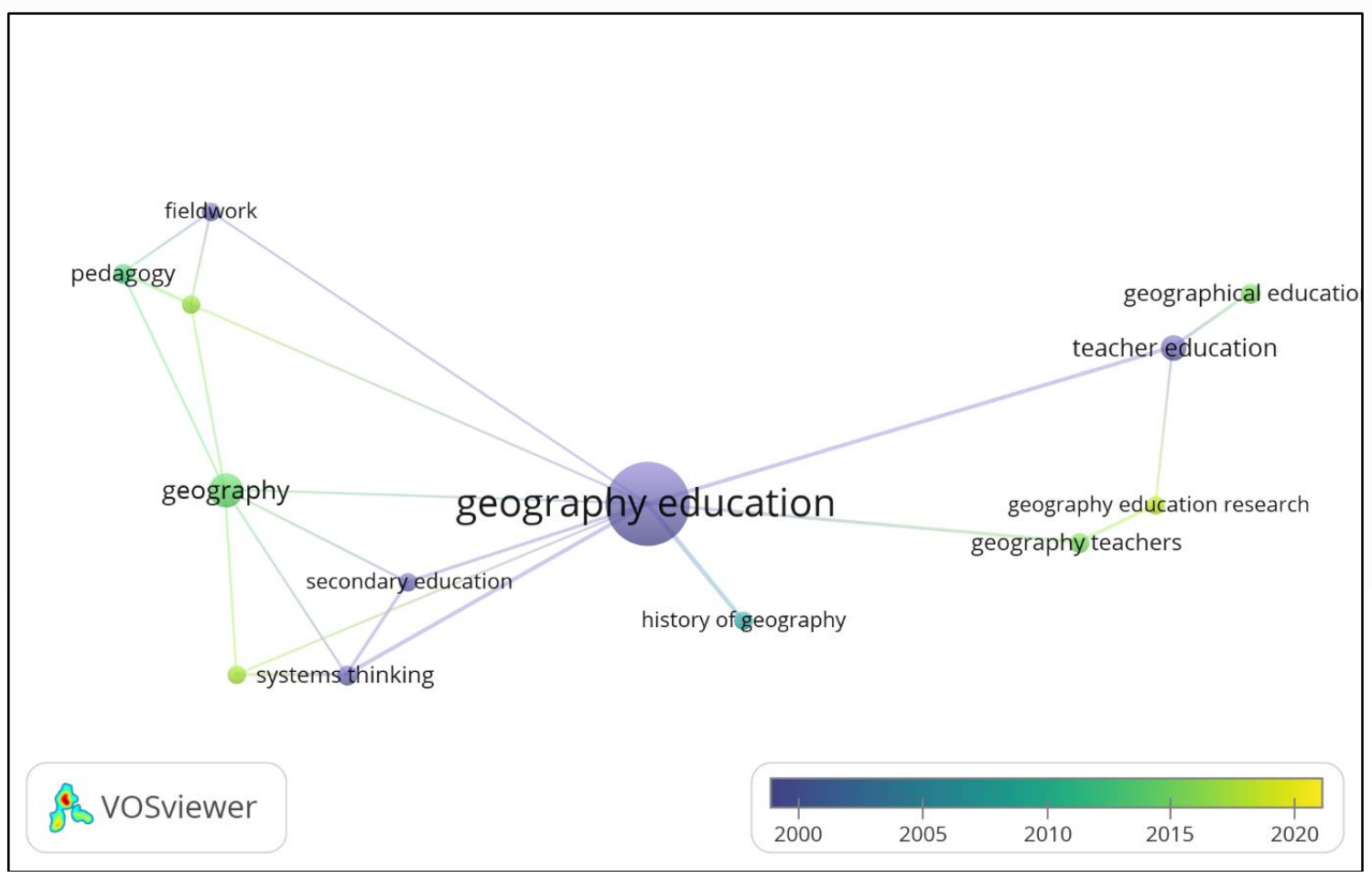

Figure 1. Keywords and current subject analysis $(\mathrm{N}=196)$

As a result of the review, it was observed that 535 different keywords were written in the articles. When Figure 1 is examined, it is clearly seen that the most used keywords in the articles are geography education, geography, and teacher education. Whereas the keywords of geography education, teacher education, fieldwork, and secondary education were predominantly used especially in 2000s, 
Aksoy, B.; Bozdoğan, K.; Sönmez, Ö. F. (2021). An evaluation of the publications in the field of...

there has been a tendency towards such keywords as geography, geography education research, geography teachers, and pedagogy in recent years.

The distribution of articles published on Geography Education in the Education / Educational Research category by the publication years was examined, and the findings in this context are presented in Table 3.

Table 3

Distribution of Articles Published on Geography Education in Education / Educational Research Category by Publication Years ( $N=196)$

\begin{tabular}{cccccc}
\hline $\begin{array}{c}\text { Publication } \\
\text { year }\end{array}$ & $\begin{array}{c}\text { Number of } \\
\text { records }\end{array}$ & $\%$ & $\begin{array}{c}\text { Publication } \\
\text { year }\end{array}$ & $\begin{array}{c}\text { Number of } \\
\text { records }\end{array}$ & $\%$ \\
\hline 2020 & 12 & 6.12 & 2009 & 5 & 2.55 \\
\hline 2019 & 25 & 12.75 & 2008 & 3 & 1.53 \\
\hline 2018 & 27 & 13.77 & 2007 & 8 & 4.08 \\
\hline 2017 & 24 & 12.24 & 2006 & 5 & 2.55 \\
\hline 2016 & 18 & 9.18 & 2005 & 1 & 0.51 \\
\hline 2015 & 26 & 13.26 & 2003 & 1 & 0.51 \\
\hline 2014 & 6 & 3.06 & 2001 & 1 & 0.51 \\
\hline 2013 & 7 & 3.57 & 2000 & 4 & 2.04 \\
\hline 2012 & 11 & 5.61 & 1994 & 1 & 0.51 \\
\hline 2011 & 6 & 3.06 & 1991 & 1 & 0.51 \\
\hline 2010 & 3 & 1.53 & 1989 & 1 & 0.51 \\
\hline
\end{tabular}

Considering the articles published on Geography Education in the Education / Educational Research category, it was concluded that the most articles were published in 2018 (27 articles). It was also observed that this publication year was respectively followed by 2015 (26 articles), 2019 (25 articles), 2017 (24 articles), and 2016 (18 articles). It can be seen that 54.08\% (106 articles) of the published articles have been published in the last five years.

The data related to the citation status of articles on Geography Education in the Education / Educational Research category by years are presented in Figure2.

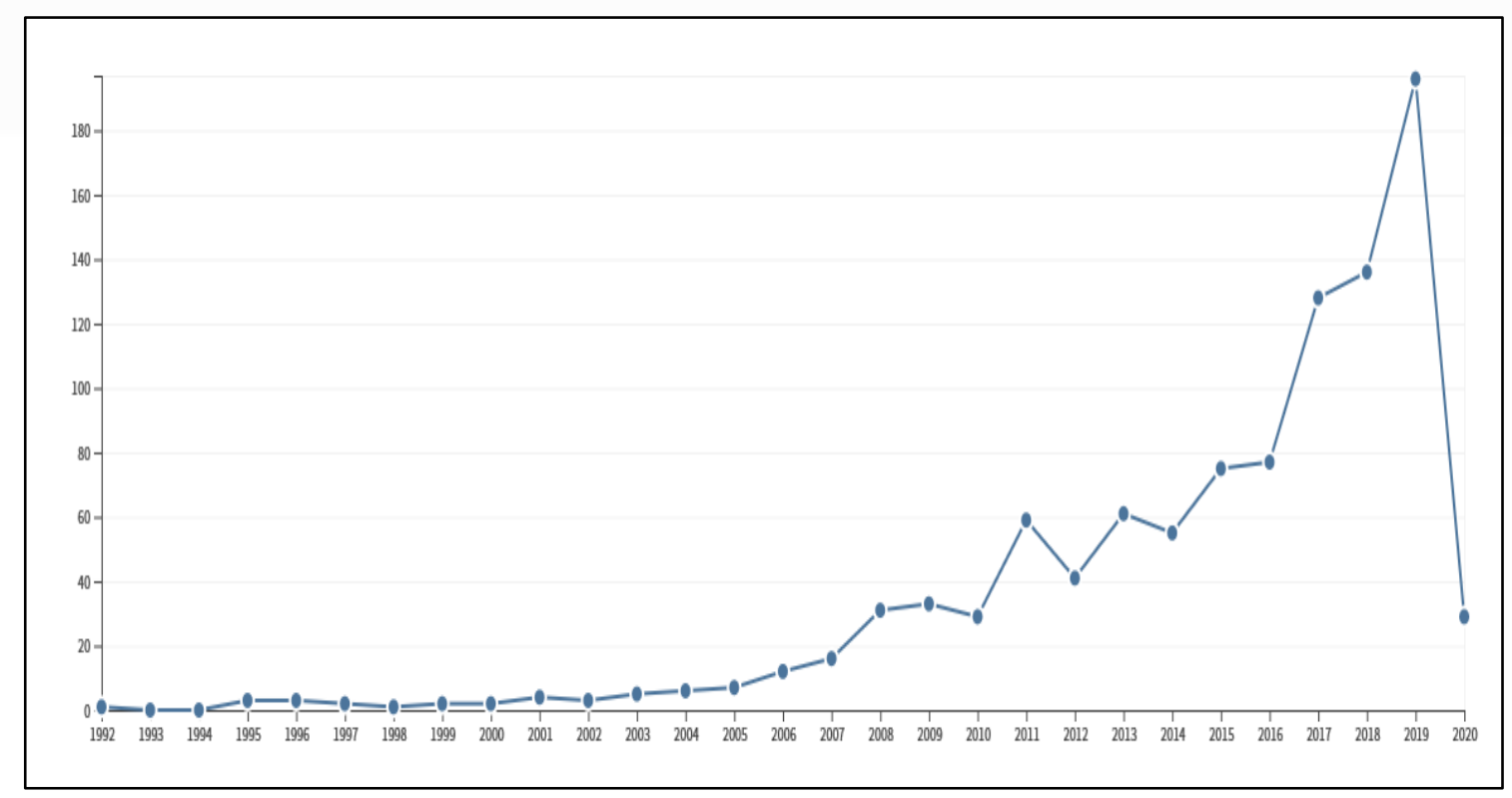

Figure 2. Citation status of the articles by years $(\mathrm{N}=196)$ 
In the Education / Educational Research category, the total number of citations to articles published on Geography Education was calculated as 1017, and the total citation average was seen as 5.19 , and the $\mathrm{h}$-index value was determined as 16.

The citation status of articles published on Geography Education in the Education / Educational Research category was examined, and the related findings are presented in Table 4.

Table 4

Top 10 Most-Cited Articles on Geography Education in Education / Educational Research Category

\begin{tabular}{|c|c|c|c|c|c|}
\hline Title of Article & Author(s) & $\begin{array}{l}\text { Publica } \\
\text { tion } \\
\text { year }\end{array}$ & $\begin{array}{l}\text { Name of } \\
\text { Journal }\end{array}$ & $\begin{array}{l}\text { Total } \\
\text { citation } \\
\text { number }\end{array}$ & $\begin{array}{l}\text { Citation } \\
\text { rate by } \\
\text { years }\end{array}$ \\
\hline $\begin{array}{l}\text { 1. Implementing curriculum } \\
\text { guidance on environmental } \\
\text { education: the importance of } \\
\text { teachers' beliefs }\end{array}$ & $\begin{array}{l}\text { Cotton, } \\
\text { DRE }\end{array}$ & 2006 & $\begin{array}{l}\text { Journal of } \\
\text { Curriculum } \\
\text { Studies }\end{array}$ & 58 & 3,87 \\
\hline $\begin{array}{l}\text { 2. Geography's place in higher } \\
\text { education in the United States }\end{array}$ & $\begin{array}{l}\text { Murphy, } \\
\text { Alexander } \\
\text { B. }\end{array}$ & 2007 & $\begin{array}{l}\text { Journal of } \\
\text { Geography } \\
\text { in Higher } \\
\text { Education }\end{array}$ & 52 & 3,71 \\
\hline $\begin{array}{l}\text { 3. The problems of utilizing } \\
\text { 'direct experience' in geography } \\
\text { education }\end{array}$ & Nairn K. & 2005 & $\begin{array}{l}\text { Journal of } \\
\text { Geography } \\
\text { in Higher } \\
\text { Education }\end{array}$ & 51 & 3,19 \\
\hline $\begin{array}{l}\text { 4. Mapping Out Geography - An } \\
\text { Example Of Epistemology And } \\
\text { Education }\end{array}$ & $\begin{array}{l}\text { Gregg, M; } \\
\text { Leinhardt, } \\
\text { G }\end{array}$ & 1994 & $\begin{array}{l}\text { Review of } \\
\text { Educational } \\
\text { Research }\end{array}$ & 36 & 1,33 \\
\hline $\begin{array}{l}\text { 5. Phenomenography: An } \\
\text { approach to research into } \\
\text { geography education }\end{array}$ & Trigwell, K & 2006 & $\begin{array}{l}\text { Journal of } \\
\text { Geography } \\
\text { in Higher } \\
\text { Education }\end{array}$ & 31 & 2,07 \\
\hline $\begin{array}{l}\text { 6. The impact of blended } \\
\text { learning model on student } \\
\text { attitudes towards } \\
\text { Geography course and their } \\
\text { critical thinking dispositions } \\
\text { and levels }\end{array}$ & $\begin{array}{l}\text { Korkmaz, } \\
\text { Ozgen; } \\
\text { Karakuş, } \\
\text { Ufuk }\end{array}$ & 2009 & $\begin{array}{l}\text { Turkısh } \\
\text { Online } \\
\text { Journal of } \\
\text { Educational } \\
\text { Technology }\end{array}$ & 26 & 2,17 \\
\hline $\begin{array}{l}\text { 7. Geography in higher } \\
\text { education in Australia }\end{array}$ & $\begin{array}{l}\text { Gibson, } \\
\text { Chris }\end{array}$ & 2007 & $\begin{array}{l}\text { Journal of } \\
\text { Geography } \\
\text { in Higher } \\
\text { Education }\end{array}$ & 25 & 1,79 \\
\hline $\begin{array}{l}\text { 8. Is distance education a } \\
\text { faustian bargain? }\end{array}$ & DiBiase, D & 2000 & $\begin{array}{l}\text { Journal of } \\
\text { Geography } \\
\text { In Higher } \\
\text { Education }\end{array}$ & 25 & 1,19 \\
\hline $\begin{array}{l}\text { 9. 'None of us sets out to hurt } \\
\text { people': The ethical geographer } \\
\text { and geography curricula in } \\
\text { higher education }\end{array}$ & $\begin{array}{l}\text { Boyd, } \\
\text { William } \\
\text { (Bill) E.; } \\
\text { Healey, } \\
\text { Ruth L.; } \\
\text { Hardwick, }\end{array}$ & 2008 & $\begin{array}{l}\text { Journal of } \\
\text { Geography } \\
\text { in Higher } \\
\text { Education }\end{array}$ & 24 & 1,85 \\
\hline
\end{tabular}


Aksoy, B.; Bozdoğan, K.; Sönmez, Ö. F. (2021). An evaluation of the publications in the field of...

\begin{tabular}{|c|c|c|c|c|c|}
\hline & $\begin{array}{l}\text { Susan W.; } \\
\text { et al. }\end{array}$ & & & & \\
\hline $\begin{array}{l}\text { 10. Geography in higher } \\
\text { education in the UK }\end{array}$ & $\begin{array}{l}\text { Sidaway, } \\
\text { James D.; } \\
\text { Johnston, } \\
\text { Ron J. }\end{array}$ & 2007 & $\begin{array}{l}\text { Journal of } \\
\text { Geography } \\
\text { in Higher } \\
\text { Education }\end{array}$ & 24 & 1,71 \\
\hline
\end{tabular}

When Table 4 is examined, it is comprehended that the most-cited study in the Education / Educational Research category is the article published in the "Journal of Curriculum Studies" and entitled as "Implementing curriculum guidance on environmental education: the importance of teachers' beliefs". A total of 58 citations were made to this article published in 2006, and the average annual citation is 3.87. This article is followed by an article with a total of 52 citations and 3.71 citation average published in 2007 in the "Journal of Geography in Higher Education" by B. Alexander Murphy and another article with 51 citations and 3.19 citation average published by K. Nairn in the same journal.

Within the scope of articles published on Geography Education in the Education / Educational Research category, the number of researchers and publications that made the most contribution to the field were examined, and the findings are provided in Table 5.

Table 5

Number of Authors and Publications Contributing to the Field Most Within the Scope of Geography Education in Education / Educational Research Category ( $N=196)$

\begin{tabular}{lccc}
\hline Authors & $\begin{array}{c}\text { Number of } \\
\text { records }\end{array}$ & Authors & $\begin{array}{c}\text { Number of } \\
\text { records }\end{array}$ \\
\hline 1. Butt, G. & 8 & 9. Kuiper, W. & 3 \\
\hline 2. Van Der Schee, J. & 7 & 10. Bakx, A. & 3 \\
\hline 3. Solem, M. & 5 & 11. Bent, G.J. & 2 \\
\hline 4. Beneker, T. & 4 & 12. Blankman, M. & 2 \\
\hline 5. Klein, P. & 4 & 13. Boogaard, M. & 2 \\
\hline 6. Seow, T. & 4 & 14. Bosschaart, A. & 2 \\
\hline 7. Bourke, T. & 3 & 15. Budke, A. & 2 \\
\hline 8. Golightly, A. & 3 & & \\
\hline
\end{tabular}

Considering Table 5, it was determined that 330 different authors (single author / multi author) published some articles contributing to the field. According to Table 5, the most contributing authors were respectively G. Butt (8 articles), J. Van Der Schee (7 articles), and M. Solem (5 articles).

The journals that are active within the scope of articles published on Geography Education in the Education / Educational Research category were examined, and the journals that published more than three articles are presented in Table 6 . 
Table 6

Journals Effective within the Scope of Articles Published On Geography Education in Education / Educational Research Category $(N=196)$

\begin{tabular}{|c|c|c|}
\hline Journals of Published Articles & $\begin{array}{l}\text { Number } \\
\text { of } \\
\text { records }\end{array}$ & $\%$ \\
\hline 1. Journal of Geography in Higher Education & 61 & 31.12 \\
\hline $\begin{array}{l}\text { 2. International Research in Geographical and } \\
\text { Environmental } \\
\text { Education }\end{array}$ & 39 & 19.89 \\
\hline 3. International Perspectives on Geographical Education & 18 & 9.18 \\
\hline 4. Geography Education for Global Understanding & 10 & 5.10 \\
\hline $\begin{array}{l}\text { 5. Geography Education Research in The UK Retrospect } \\
\text { and } \\
\text { Prospect the UK Case Within The Global Context }\end{array}$ & 8 & 4.08 \\
\hline 6. Education Sciences & 5 & 2.55 \\
\hline 7. Geosaberes & 5 & 2.55 \\
\hline 8. Educational Sciences in Theory and Practice & 5 & 2.55 \\
\hline 9. Computers Education & 3 & 1.53 \\
\hline 10.Education and Science & 3 & 1.53 \\
\hline
\end{tabular}

According to Table 6, it was seen that the articles were published in 58 different journals. In this context, when Table 6 is examined, it is observed that the most articles are published in the "Journal of Geography in Higher Education" (61 articles). This is respectively followed by "International Research in Geographical and Environmental Education" (39 articles), "International Perspectives on Geographical Education" (18 articles), and "Geography Education for Global Understanding" (10 articles).

The articles published on Geography Education in the Education / Educational Research category were examined, and the most-cited journals and the citation networks are presented in Figure 3. 


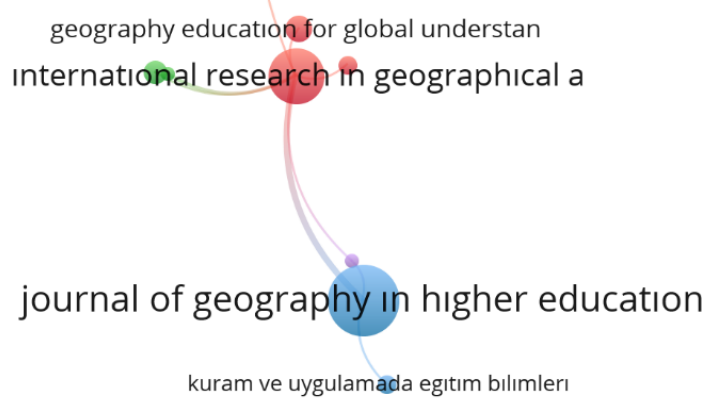

Figure 3. Top-Cited Journals and Citation Networks ( $\mathrm{N}=196)$

Accordingly, it was obtained that the articles in 58 different journals were cited. When Figures 3 is analyzed, it is seen that the journal that gets the most citation is "Journal of Geography in Higher Education". This is followed by such journals called as "International Research in Geographical and Environmental Education", "Geography Education for Global Understanding", and "Educational Sciences in Theory and Practice".

The countries in which the articles on Geography Education are published in the Education / Educational Research category were examined, and the countries with more than three publications are presented in Table 7.

Table 7

Countries Active within the Scope of Articles Published on Geography Education in the Education / Educational Research Category $(N=196)$

\begin{tabular}{lcclcc}
\hline Country & $\begin{array}{c}\text { Number } \\
\text { of records }\end{array}$ & $\%$ & Country & $\begin{array}{c}\text { Number } \\
\text { of } \\
\text { records }\end{array}$ & $\%$ \\
\hline 1. The USA & 46 & 23,45 & 9. New Zealand & 7 & 3.57 \\
\hline 2. England & 32 & 16.32 & 10. Singapore & 7 & 3.57 \\
\hline 3. Australia & 20 & 10.20 & 11. South Korea & 6 & 3.06 \\
\hline 4. Turkey & 18 & 9.18 & 12. Spain & 6 & 3.06 \\
\hline 5. The Netherlands & 15 & 7.65 & 13. Brazil & 5 & 2.55 \\
\hline 6. Germany & 9 & 4.59 & 14. South Africa & 5 & 2.55 \\
\hline 7. Canada & 8 & 4.08 & 15. Finland & 4 & 2.04 \\
\hline 8. China & 8 & 4.08 & & & \\
\hline
\end{tabular}


When Table 7 is examined, it was observed that the most articles were published in the United States (49 articles), and this country is respectively followed by England (article 32), Australia (20 articles), and Turkey (18 articles).

The institutions of the researchers publishing articles on Geography Education in the Education / Educational Research category were examined, and the institutions that published three or more articles are presented in Table 8.

Table 8

Ranking of the Top Ten Institutions Effective within the Scope of Articles Published on Geography Education in the Education / Educational Research Category ( $N=196)$

\begin{tabular}{lcc}
\hline Institutions & $\begin{array}{c}\text { Number of } \\
\text { records }\end{array}$ & $\%$ \\
\hline 1. Oxford Brookes University & 9 & 4.61 \\
\hline 2. Vrije University & 9 & 4.61 \\
\hline 3. Utrecht University & 7 & 3.59 \\
\hline 4. Texas State University & 5 & 2.56 \\
\hline 5. East China Normal University & 4 & 2.05 \\
\hline 6. Nanyang Technological University & 4 & 2.59 \\
\hline 7. Queensland University of Technology & 4 & 2.59 \\
\hline 8. Texas A \& M University & 4 & 2.05 \\
\hline 9. University of Northern Colorado & 4 & 2.05 \\
\hline 10. Arizona State University & 3 & 1.53 \\
\hline
\end{tabular}

Considering the findings in Table 8, it was determined that the articles published on Geography Education in the Education / Educational Research category belong to the researchers from 210 different institutions. When Table 8 is examined, it is seen that the institution where the most studies are published is Oxford Brookes University and Vrije University (9 articles for each), and these universities are respectively followed by Utrecht University with seven publications and Texas State University with 5 publications.

The publication languages of the articles published on Geography Education in the Education / Educational Research category are presented in Table 9.

Table 9.

Publication Languages Effective within the Scope of Articles on Geography Education in Education / Educational Research Category ( $N=196)$

\begin{tabular}{lcc}
\hline Publication Language & Number of records & Percent \\
\hline English & 182 & 92.85 \\
Portuguese & 5 & 2.55 \\
Spanish & 5 & 2.55 \\
Turkish & 3 & 1.53 \\
French & 1 & 0.51 \\
\hline
\end{tabular}

According to Table 9, 182 published articles appear to be written in English, and 3 articles were published in Turkish.

The funds supporting the articles published on Geography Education in the Education / Educational Research category were examined, and the top five institutions are presented in Table 10. 
Aksoy, B.; Bozdoğan, K.; Sönmez, Ö. F. (2021). An evaluation of the publications in the field of...

Table 10

Funds Supporting the Published Articles on Geography Education in Education / Educational Research Category ( $N=196)$

\begin{tabular}{lcc}
\hline Funds & $\begin{array}{c}\text { Number of } \\
\text { records }\end{array}$ & Percent \\
\hline 1. German Research Foundation DFG & 2 & 1.02 \\
\hline 2. Hong Kong Research Grants Council & 2 & 1.02 \\
\hline $\begin{array}{l}\text { 3. Aim For Top University Project of National Taiwan } \\
\text { Normal University NTNU }\end{array}$ & 1 & 0.51 \\
\hline 4. Australian Research Council & 1 & 0.51 \\
\hline $\begin{array}{l}\text { 5. CEGOT Centre For Studies in Geography and Spatial } \\
\text { Planning Foundation For Science and Technology FCT }\end{array}$ & 1 & 0.51 \\
Under The Compete Project & & \\
\hline
\end{tabular}

Examining Table 10, it was concluded that 172 different funds supported the published articles on this field. According to Table 10, it is seen that the total 4 articles are supported by "German Research Foundation DFG" and "Hong Kong Research Grants Council". The institutions called as "Aim for Top University Project of National Taiwan Normal University NTNU", "Australian Research Council", and "CEGOT Center for Studies in Geography and Spatial Planning Foundation For Science and Technology FCT Under The Compete Project Hankuk University of Foreign Studies" supported 1 article for each.

The records of 18 articles published in Turkey in Education / Educational Research category were examined. It is seen that the total number of citations is 64 and that the average of total citations is 3.56. According to the citation number of 18 articles, the first five articles are presented in Table 11.

Table 11

The Articles on Geography Education Published in Turkey in Education / Educational Research Category (Total Citation Number $=47$, Total Citation Average $=1.18$ )

\begin{tabular}{|c|c|c|c|c|c|}
\hline Title of Article & Author(s) & $\begin{array}{l}\text { Publication } \\
\text { year }\end{array}$ & $\begin{array}{l}\text { Name of } \\
\text { Journal }\end{array}$ & $\begin{array}{c}\text { Total } \\
\text { Citation } \\
\text { Number }\end{array}$ & $\begin{array}{c}\text { Number } \\
\text { of } \\
\text { Citations } \\
\text { / Year }\end{array}$ \\
\hline $\begin{array}{l}\text { 1. The Impact of Blended } \\
\text { Learnıng Model on } \\
\text { Student Attitudes Towards } \\
\text { Geography Course and } \\
\text { Their Critical Thinking } \\
\text { Dispositions and Levels }\end{array}$ & $\begin{array}{l}\text { Korkmaz, } \\
\text { Özgen; } \\
\text { Karakuş, } \\
\text { Ufuk }\end{array}$ & 2009 & $\begin{array}{l}\text { Turkish } \\
\text { Online } \\
\text { Journal of } \\
\text { Educational } \\
\text { Technology }\end{array}$ & 26 & 2,17 \\
\hline $\begin{array}{l}\text { 2. The Contribution of } \\
\text { Geographic Information } \\
\text { Systems (GIS) to } \\
\text { Geography Education and } \\
\text { Secondary School } \\
\text { Students' Attitudes } \\
\text { Related to GIS }\end{array}$ & $\begin{array}{l}\text { Artvinli, } \\
\text { Eyüp }\end{array}$ & 2010 & $\begin{array}{l}\text { Educational } \\
\text { Sciences in } \\
\text { Theory and } \\
\text { Practice }\end{array}$ & 7 & 0,64 \\
\hline $\begin{array}{l}\text { 3. The Impact of Mobile } \\
\text { Augmented Reality in } \\
\text { Geography Education: } \\
\text { Achievements, Cognitive } \\
\text { Loads and Views of }\end{array}$ & $\begin{array}{l}\text { Turan, } \\
\text { Zeynep; } \\
\text { Meral, Elif; } \\
\text { Şahin, } \\
\text { İbrahim }\end{array}$ & 2018 & $\begin{array}{l}\text { Journal of } \\
\text { Geography in } \\
\text { Higher } \\
\text { Education }\end{array}$ & 5 & 1,67 \\
\hline
\end{tabular}




\begin{tabular}{|c|c|c|c|c|c|}
\hline University Students & Fevzi & & & & \\
\hline $\begin{array}{l}\text { 4. Multicultural Group } \\
\text { Work on Field Excursions } \\
\text { to Promote Student } \\
\text { Teachers' Intercultural } \\
\text { Competence }\end{array}$ & $\begin{array}{l}\text { Brendel, } \\
\text { Nina; Akşit, } \\
\text { Fisun; Akşit, } \\
\text { Selahattin }\end{array}$ & 2016 & $\begin{array}{l}\text { Journal of } \\
\text { Geography in } \\
\text { Higher } \\
\text { Education }\end{array}$ & 5 & 1 \\
\hline $\begin{array}{l}\text { 5. Turkey: GIS for } \\
\text { Teachers and the } \\
\text { Advancement of GIS in } \\
\text { Geography Education }\end{array}$ & Demirci, Ali & 2012 & $\begin{array}{l}\text { International } \\
\text { Perspectives } \\
\text { on Teaching } \\
\text { and Learning } \\
\text { With GIS in } \\
\text { Secondary } \\
\text { Schools }\end{array}$ & 4 & 0,44 \\
\hline
\end{tabular}

When Table 11 is examined, it is seen that the first Turkey-originated article with 26 citations on the related subject is the article, entitled as "The impact of blended learning model on student attitudes towards geography course and their critical thinking dispositions and levels", published by Özgen Korkmaz ve Ufuk Karakuş in the "Turkish Online Journal of Educational Technology" in 2009. This article is followed by the article with 7 citations entitled as "The Contribution of Geographic Information Systems (GIS) to Geography Education and Secondary School Students' Attitudes Related to GIS" published in the journal of "Educational Sciences in Theory and Practice" in 2010 and by the article with 5 citations entitled as "The Impact of Mobile Augmented Reality in Geography Education: Achievements, Cognitive Loads and Views of University Students" published in the "Journal of Geography in Higher Education" in 2018.

\section{Result and Discussion}

Through the research, 559 of the $64,874,978$ studies registered in the WoS database between 1975 and March 1, 2020 were determined to be related to Geography Education. It was observed that 196 (35.06\%) of these studies were included in the education / educational research category. It can be stated that approximately one third of the studies on geography education in the WoS database are in the category of education / educational research.

As a result of the analyses, it was concluded that the most common type of publication related to Geography Education was the articles with a total number of 196. It can be expressed that this publication type is mostly preferred as the articles present concrete and objective indicators in the academic studies and productivity of scientists. In the literature, there are some studies with similar findings (Bozdoğan, 2020; Chao, Yang \& Jen, 2007; Chiu \& Ho, 2007; Karagöz \& Koç Ardıç, 2019; Karagöz \& Şeref, 2019; Koley \& Sen, 2016; Tsay \& Yang, 2005).

According to another finding of the study, a total of 535 different keywords were found in 196 articles. It is also observed that the most used keywords in the articles are geography education, geography, and teacher education.

In addition, it was determined that the most articles in the category of Education / Educational research related to Geography Education were published 
in 2018 (27 articles). 106 of the published articles (54.08\%) appeared to have been published in the last five years. Therefore, it can be stated for this rate that it has found more place in the educational researches related to Geography Education in recent years. According to another finding, the number of authors contributing to the field was determined as 330. In this context, the most effective authors are respectively "Butt, G.", "Van Der Schee, J.", and "Solem, M.".

It was determined that 196 articles published in the Education / Educational Research category received a total of 1017 citations at the time of the screening and that the average citation was 5.19. In this context, it was seen that the mostcited study was DRE, the article by Cotton titled as "Implementing curriculum guidance on environmental education: the importance of teachers' beliefs" published in the journal "Journal of Curriculum Studies".

According to another result, the published articles were found to be published in 58 different journals. In this context, it is concluded that the most effective journal is the "Journal of Geography in Higher Education". This journal is followed by such journals as "International Research in Geographical and Environmental Education" and "International Perspectives on Geographical Education".

It is seen that the journal with the most citation in this field is "Journal of Geography in Higher Education". This journal is followed by the journals of "International Research in Geographical and Environmental Education", "Geography Education for Global Understanding", and "Educational Sciences in Theory and Practice". It was also revealed that the most frequent citations were among the first two journals in question. The most published and cited journals are the prestigious journals covering the studies on geography and geography education.

At the end of the analyses, it was seen that the researchers from 25 different countries published some articles that contributed to the field. In this context, the most active countries is the United States, and this country is followed by the UK, Australia, and Turkey. That Turkey with 18 articles is at the $4^{\text {th }}$ rank among the first 15 different countries indicates that this country has included this subject in the studies at a positive level.

According to the results of the analysis, the names of 210 different institutions are included in the published articles. In this context, it is determined that the most active institutions are "Oxford Brookes University" and "Vrije University", and these universities are followed by "Utrecht University", "Texas State University", and "East China Normal University". Karadeniz Technical University with three publications from Turkey took its place among the institutions that contribute to that area. According to another result, 172 different funds were determined to support the published articles. In this context, 4 articles are supported by the "German Research Foundation DFG" and "Hong Kong Research Grants Council", and these institutions are followed by "Aim For Top University Project of National Taiwan Normal University NTNU", "Australian Research Council", and "CEGOT Center For Studies In Geography and Spatial Planning Foundation For Science and Technology FCT Under The Compete Project" (1 article for each). It can also be stated that the fact that the funds support scientific research contributes positively 
to the number of publications. Hence, it can be concluded that the support of both TUBITAK and Research Project of the universities in Turkey (RP) to such kind of researches can positively contribute to the number of the publications.

When the publication languages of the published articles were examined, it was determined that 182 articles (92.85\%) were written in the English language. It can be said that this situation can be considered normally due to the acceptance of the language of communication in the international academic community in English. The primary publication language of the journals in the WoS database and many other databases can be interpreted as being effective in this finding. Similar findings are seen in many previous studies (Bordons and Barrigón, 1992; MacíasChapula and Mijangos-Nolasco, 2002; Tsay, 2008).

According to the analysis, it is also observed that there are some articles written on this subject in Turkey. In this context, a total of 18 articles were identified, and the total number of citations received by these articles was 64, and the average total citation was 3.56. The first article on this subject in Turkey was published in the journals indexed in the WoS in 2009.

The articles related to the subject of Geography Education in the Education / Educational Research category in the WoS database were examined in this study. In this context, the limitation of the study is only the researches that is within the scope of WoS data. Therefore, the further researches on this subject can be conducted by searching the larger databases.

\section{Suggestions}

Especially in databases such as Scopus and ProQuest, there is a need for researches aiming to determine the effectiveness of the academic field related to Geography education. It is thought that the factors affecting the developments in the field of Geography Education should be closely monitored and an effective cooperation should be made in the direction of publishing with geography education scientists. This situation may increase the scientific communication of the field of Geography education with other disciplines and allow publications to receive more citations. Finally, researchers can make a positive contribution to geography education by taking into the scope of examination, in addition to articles, books, book chapters, or papers presented at congresses in their future studies. 


\section{References}

Akınoğlu, O. (2005). The effectiveness of and problems in geography education. Marmara Coğrafya Dergisi. (12), 77-96.

Artvinli, E. (2009). Approaches of geography teachers to geographical information systems gıs. Balıkesir Sosyal Bilimler Enstitüsü Dergisi. 12 (22), 40-57.

Artvinli, E. \& Kaya, N. (2010). 1992 international charter on geographical education and its reflections in Turkey. Marmara Coğrafya Dergisi. (22), 93-127.

Balcı, A. (2012). A qualitative study on teaching geographical features of Turkey with descriptive activities. Marmara Coğrafya Dergisi. (26), 216-259.

Bednarz, S. W., S. Heffron \& N. T. Huynh (eds). (2013). A Road Map for 21st Century Geography Education: Geography Education Research (A report from the Geography Education Research Committee of the Road Map for 21st Century Geography Education Project). Washington: D.C Association of American Geographers

Bordons, M. \& Barrigón, S. (1992). Bibliometric analysis of publications of Spanish pharmacologists in the SCI (1984-89). Part II. Scientometrics. 25 (3), 425-446.

Bozdoğan, K. (2020). A Bibliometric Analysis of Educational Studies About "Museum Education". Participatory Educational Research. 7 (3), 161-179

Brooks, C. (2010). How does one become a researcher in geography education?. International Research in Geographical and Environmental Education. 19 (82), 113116.

Butt, G. \& Lambert, D (2014). International perspectives on the future of geography education and the role of national standards. International Research in Geographical and Environmental Education. 23 (1), 1-12.

Chao, C. C., Yang, J. M. \& Jen, W. Y. (2007). Determining technology trends and forecasts of RFID by a historical review and bibliometric analysis from 1991 to 2005. Technovation. 27 (5), 268-279.

Chiu, W. T. \& Ho, Y. S. (2007). Bibliometric analysis of tsunami research. Scientometrics. 73 (1), 3-17.

Cotton, D. R. E. (2006). İmplementing curriculum guidance on environmental education: the importance of teachers' beliefs. Journal of Curriculum Studies. 38 (1), 67-83.

Çifçi, T. (2017). The trends of postgraduate theses (2006-2017) on geography education in Turkey. Journal of History Culture and Art Research. 6 (4), 864-887.

Demiralp, N. (2007). Materials in geography education and the geography curriculum 2005. Kastamonu Eğitim Dergisi. 15 (1), 373-384.

Değirmenci, Y. (2019). Investigation of teachers' opinions on teaching geography subjects in 4th class social studies course. Manas Sosyal Araştırmalar Dergisi. 8 (4), 32863305 .

Demirgil, H. (2018). Scientific concentration fields and bibliometrics networks in süleyman demirel university publications. Süleyman Demirel Üniversitesi Fen Edebiyat Fakültesi Fen Dergisi. 13(2), 36-53.

Diodato V. (1994). Dictionary of Bibliometric. Haworth Press: Binghamton, NY.

Geçit, Y. (2010). Primary tendencies in research on geography education. Kuram ve Uygulamada Eğitim Bilimleri. 10(2), 923-987. 
Gökçe, N. \& Öztürk, F. (2013). Primary school students' perception about issues related to geography science. Mehmet Akif Ersoy Üniversitesi Eğitim Fakültesi Dergisi. 13 (25), 92-118.

Gregg, M. \& Leinhardt, G. (1994). Mapping out geography - an example of epistemology and education. Review of Educational Research. 64 (82), 311-361.

Gibson, C. (2007). Geography in higher education in Australia. Journal of Geography in Higher Education. 31(1), 97-119.

İncekara, S. (2009). The international research in geography education and the examples from Turkey: present situation and future directions. Doğu Coğrafya Dergisi. 14(21), 123-136.

Karagöz, B. \& Koç Ardıç, İ. (2019). Bibliometric analysis of the articles published in journal of mother tongue education. Ana Dili Eğitimi Dergisi. 7(2), 419-435.

Karagöz, B. \& Șeref, İ. (2019). Bibliometric analysis of researches on Yunus Emre. Akdeniz Eğitim Araştırmaları Dergisi. 13 (27), 123-141.

Karasu, Z. \& Ünlü, M. (2006). The effect of achievement academic of constructive method in geography education. Marmara Coğrafya Dergisi. (12), 105-128.

Kaya, M. F. (2013). Tendencies in geography education: a meta-analysis study on graduate theses up to 2012. Marmara Coğrafya Dergisi. (27), 282-313.

Kılcan, B., Çetin, T., Ablak, S. \& Gürgür, M. (2019). Developing scale of attitude towards human geography course: validity and reliability study. Cumhuriyet International Journal of Education. 8 (4), 913-927.

Kızılçaoğlu, A. (2003). Secondary schools geography textbook's evaluation criterions. Marmara Coğrafya Dergisi. (8), 19-33.

Kızılçaoğlu, A. \& Taş, H. (2007). Secondary school geography education in new curriculum: the subject matter and geographic skills. Marmara Coğrafya Dergisi. (16), 93-108.

Koç, H., Aksoy, B., Sönmez, Ö.F. \& Yeşiltaş, E. (2010). The activities making students active during teaching process and geography teaching depending on activities. Sosyal Bilimler Araştırmaları Dergisi. (2), 181-196

Koç, H. \& Aksoy, B. (2010). The evaluation of the views of teachers concerning the teaching program of 2005 geography course. Karadeniz Sosyal Bilimler Dergisi. (2), 17-53.

Koç, H., Sönmez, Ö. F. \& Çifçi, T (2012). Types of texts that have been used in secondary education geography course books. Atatürk Üniversitesi Sosyal Bilimler Dergisi. 12 (48), 17-39.

Koley, S. ve Sen, B. K. (2016). Biobibliometric study of Professor A. S. Paintal, a celebrated medical physiologist, Library Herald, 54 (2), 174-190.

Korkmaz, Ö. \& Karakuș, U. (2009). The impact of blended learning model on student attitudes towards geography course and their critical thinking dispositions and levels. The Turkish Online Journal of Educational Technology. (8), 51-63.

Macías-Chapula, C. \& Mijangos-Nolasco, A. (2002). Bibliometric analysis of AIDS literature in Central Africa. Scientometrics. 54(2), 309-317.

Murphy, Alexander B. (2007). Geography's place in higher education in the United States. Journal of Geography in Higher Education. 31 (1), 121-41.

Nairn, K (2005). The problems of utilizing 'direct experience' in geography education. Journal of Geography in Higher Education. (29) 293-309 
Reaves, EJ., Valle, R., Chandrasekera, R.M., Soto, G., Burke, R.L., Cummings, J.F, Bausch, D.G. \& Kasper, M.R. (2017). Use of bibliometric analysis to assess the scientific productivity and impact of the global emerging infections surveillance and response system program, 2006-2012. Military Medicine. 182(5), 1749-1756.

Sönmez, Ö. F., Koç, H. \& Çifçi, T. (2013). Analysis of geography questions asked in OSS, LYS and YGS exams in terms of cognitive domain level according to bloom's taxonomy. Karadeniz Araştırmaları Dergisi. (36), 257-275.

Tsay, M. Y. (2008). A bibliometric analysis of hydrogen energy literature, 1965-2005. Scientometrics. 75 (3), 421-438.

Tsay, M. Y., \& Yang, Y. H. (2005). Bibliometric analysis of the literature of randomized controlled trials. Journal of the Medical Library Association. 93 (4), 450-458.

Yıldırım, A. \& Şimşek, H. (2013). Qualitative research methods in the social sciences (8th ed.). Ankara: Seçkin Yayıncılık.

\section{Biographical Statements}

Bülent AKSOY lectures in the department of social studies education in the faculty of education at Gazi University. He carries out studies on geography education and social studies education.

Kerem BOZDOĞAN lectures as a classroom teacher at Kayseri Gözüakçalar Primary School. He carries out studies on social studies education, museum education and geography education.

Ömer Faruk SÖNMEZ lectures in the department of social studies education in the faculty of education at Tokat Gaziosmanpaşa University. He carries out studies on social studies education, geography education, values education, and citizenship education. 